\title{
Knowledge environments in universities
}

\author{
PETER MEUSBURGER ${ }^{1}$
}

\begin{abstract}
Talent, motivation, and wealth of ideas are not the only characteristics determining how successfully a scholar's research and academic career develops. What we academics call creative is never the result of individual action alone. Learning processes and research are situated in environments, organisational structures, and spatial relations. We cannot study scientific creativity by isolating scholars and their works from the social and historical milieu in which their actions are carried out. A stimulating environment and a talented individual must come together and interact before a creative process can occur. This article addresses four questions: What elements constitute a local knowledge environment? How can a local knowledge environment affect learning and research processes? How can one measure the impact of a knowledge environment and avoid the trap of determinism? What theoretical concepts can contribute to the analysis of knowledge environments and the explanation of their impact?
\end{abstract}

Keywords: knowledge environment, creativity, university, network, mobility, scholars, spatial relations, learning, research, interaction analysis, institutional theory, communicative constructionism

\section{Creative scientists can be inspired or impeded by their knowledge environment}

The broad consensus is that science has a history. But does science also have a geography? Is science not supposed to be placeless? In recent years a growing number of scholars have pointed out that the generation, diffusion, and legitimisation of scientific knowledge are influenced by local contexts, knowledge environments, spatial relations, and spaces of interaction (GIERYN, T.F. 2001, 2002; Livingstone, D.N. 1995, 2000, 2002, 2003; Meusburger, P. 2008, 2009b, 2012a,b; Meusburger, P. and Sсhuch, T. 2010a,b, 2012a,b; Ophir, A. and Shapin, S. 1991; Shapin, S. 1998, 2001; Withers, C.W.J. 2002). When research on creativity was still in its infancy, it focused on the attributes of geniuses, gifted persons, creative artists, and scientists; creative performance; and problem-solving. Few scholars found it necessary to include the environment in their considerations. At best, they admitted that talented individuals could not develop their creativity in repressive societies.
The way to the interactional and environmental study of creativity was prepared by environmental psychologists concentrating on the relation between actor, situation, and environment, especially by BARKER's concept of action settings (BARKER, R.G. 1968). Scholars pursuing management studies, organisational research, and institutional theory, too, became interested in the psychological climate of organisations, in institutional logics, and in rules and informal norms that structure behaviour (Battilana, J. 2006; Bitektine, A. and Miller, D. 2015; Lawrence, T. et al. 2011; Mintzberg, H. 1979; Suddaby, R. 2010; Suddaby, R. and Greenwood, R. 2005). They found that creative persons are very sensitive and responsive to formal and informal sets of mutual expectations between people, to quality conventions and evaluation criteria prevailing at their place of work (see RAUDSEPP, E. 1958).

Since the 1980s, more and more scholars have acknowledged that the creative scientist does not work in a social, cultural, and economic vacuum. They have pointed out that people cannot study creativity by isolating in-

\footnotetext{
${ }^{1}$ Department of Geography, Heidelberg University. Berliner Strasse 48. D-69120 Heidelberg, Germany. E-mail: peter.meusburger@geog.uni-heidelberg.de
} 
dividuals and their works from the social and historical milieu in which their actions are carried out (Amabile, T.M. 1983a,b; Amabile T.M. and GrysKiewicz, N. 1989; Amabile, T.M. et al. 1990; АмABILE, T.M. et al. 1996; Boden, M. 1994, 2004; CsiKszentmihalyi, M. 1988, 1990, 1999; Hennessey, B.A. and Amabile, T.M. 1988; Malecki, E.J. 2013; Matthiesen, U. 2009; Meusburger, P. 2009a; Meusburger, P. et al. 2009; Mumford, M.D. 1995; Runco, M.A. 1988; Runco, M.A. and OкudA, S.M. 1988; Simonton, D.K. 1975; Sternberg, R.E. and Lubart, T.I., 1991, 1999). It has been accepted that creative individuals are inspired or impeded by societal and organisational structures and that they depend on evaluators, critical audiences, research infrastructure, support of key persons, and financial resources. It has been recognised that creative people and research projects may meet with incomprehension, competition, hostility, and social conflict, that interactions play a very important role, that what we call creative is never the result of individual action alone, and that learning processes and research are situated in environments, spatial structures, and spatial relations.

Today most scholars agree that scientific practices vary from place to place and that universities and other sites of knowledge generation and knowledge distribution are not simply locations but social spaces, epistemic venues, and nodes of scientific networks. ${ }^{2}$ In each discipline university locations differ in reputation; endowment with resources; and the incentives, role models, and career opportunities they offer. They also differ in the degree to which their scholars are part of national and international scientific networks (Charle, C. 2004; GlüCKLer, J. 2013) and in the quality and motivation of their students. Different places $^{3}$ or knowledge environments have a bearing on whether and how soon new scientific concepts, practices, or techni-

\footnotetext{
${ }^{2}$ For the role of places in occupational science see RowLEs, G.D. (2008).

${ }^{3}$ Various concepts of space and place are discussed by Harvey, D. (2005) and Massey, D. (1999, 2005), for example.
}

cal innovations are accepted and acted upon and whether it is possible to discuss contested ideas, conduct expensive experiments, hear promptly of crucial developments, and meet with agreement, benevolent tolerance, or criticism upon airing new ideas or breaking the conventions of one's discipline.

Talent, motivation, and wealth of ideas are not the only characteristics determining how successfully a scholar's research and academic career develops. A stimulating environment and a talented individual must come together and interact before a creative process can occur (see Sternberg, R.E. and Lubart, T.I. 1991). The geography of science is interested in a number of questions. For example, why has a specific research field developed at university $A$ and not at universities B or C? Why have some universities produced and attracted a host of outstanding scholars, whereas others have not? Why does the large majority of outstanding scholars (e.g., Nobel Prize winners) stem from only a small number of universities? Which factors, expectations, or institutional logics inhibit or promote the potential scientific creativity of actors? Which factors influence the career and spatial mobility of scholars? Why does science travel in the selective way it does? How does a local knowledge environment affect research processes and how can these effects be explained? How do international networks of scientists evolve and which long-term consequences do they have? What are the preconditions and primary sources of paradigmatic change in various disciplines and which barriers and facilitators of change can be identified?

As creativity is domain-specific, different domains (e.g., science, humanities, arts, and fashion) need different knowledge environments. This article focuses on knowledge environments of universities. A university's knowledge environment is definable as the result of systematic interdependencies and causal interactions relevant to the generation, diffusion, and application of scientific knowledge. ${ }^{4}$ A knowledge environment should not

\footnotetext{
${ }^{4}$ Some authors prefer the term knowledge milieu.
} 
be thought of as an independent variable that directly influences all actors through a direct cause-and-effect relation (if A, then B). It is rather a locally available potential or a local range of resources. It stands for incentives, challenges, stimulations, opportunities, and support networks that can be used, overlooked, or ignored. A knowledge environment can operate as it should only if the actors involved use the local resources and interact with each other. The outcomes of human interactions and experiences in life are always indeterminate. No one can predict the results of appropriation and interaction, whether and how often the local potential for integrating diverse viewpoints and knowledge bases will be activated, and how the relationships between creative agents will develop. Therefore, a knowledge environment's significance and effect can be analysed only after events have taken place, after the scientific careers and research results associated with that environment have become evident.

The article deals with four questions: What elements make up a local knowledge environment? How can a local knowledge environment affect learning and research processes? How can one measure the impact of a knowledge environment and avoid the trap of determinism? What theoretical concepts can contribute to the analysis of knowledge environments and the explanation of their impact?

\section{What elements make up a local knowledge environment?}

\section{Personal resources}

The most important elements of a knowledge environment at a given place are its human beings with their competencies, skills, experiences, emotions, networks, scientific reputation, manner of interacting with other people, and other personal characteristics. A university is a junction of the paths along which careers are pursued by the academics of various disciplines, generations, and provenances for a specific period of time. This intersection of career paths at a particular place (for career paths of Nobel Prize winners, see MAger, C. 2012) can channel highly diverse bodies of knowledge, research interests, theoretical concepts, international experiences, networks, quality standards, and methodological expertise into a knowledge environment, or space of thematic communication, where they undergo critical discussion and where their value is tested in research processes.

Because people are the most important part of a knowledge environment and because their interactions, learning processes, and conflicts are not foreseeable, a knowledge environment is never stable or immutable; it is constantly changing. If a university's knowledge environment is to remain attractive, competitive, and resilient in its quality and scientific reputation, it must be continually replenished by the best available candidates bringing in new ideas, new competence, new scientific methods, and new networks. Scholars socialised in other knowledge environments will question or subtly change some of the prevailing institutional logics, interpretations, and justifications and will bring in new research interests, new kinds of organisational structures, and new repertoires of scientific practices. Some scholars criticizing the theoretical mainstream in their discipline will have an interest in counter-hegemonic practices (see CLEGG, S. 2010, p. 8), and some of them will even be able to exert important effects on governance structures (DAcin, M.T. et al. 2002, 51-52).

A knowledge environment operates by the Matthew effect: The more you have, the more you get. The higher the scientific reputation of a university, the more it acts as a magnet attracting talent and brains, and the more impressive its global networks are. Creative, talented people tend to be attracted to certain institutions and places where they can develop their abilities and ideas, have the occasions to interact with other knowledgeable agents, procure the necessary support, be inspired, tackle challenges, and command the necessary resources. 
This kind of constant renewal comes about not only through the recruitment of new scholars ${ }^{5}$ but also through what is known as research travel, circular mobility, such as brief periods of study or research abroad, scientific cooperation, and conferences. Mobility of scholars is extremely important for universities. It can trigger new ways of thinking and learning and can bring about new cooperation in the world of science. Mobility means gathering experience in different knowledge environments, tackling new challenges in different departments and scientific domains, exposing one's research ideas to new criticism, and familiarising oneself with issues and methods one has not yet encountered at previous places of work. Learning processes and careers of scholars do not usually take place in a single environment. Scholars are expected to work successfully at more than one university or institutional setting so that they can accrue a wealth of experience, develop extensive personal networks, and constantly broaden their methodological spectrum.

The mobility of scholars can be analysed with various methods and indicators. Some of the most frequently used are the regional provenance, career paths, and scientific travel of the people in question (ACKers, L. 2005; BAAR-CANTONI, R. and Wolgast, E. 2012; Harvey, W. 2010; Heffernan, M. and JöNs, H. 2013; JöNs, H. 2007, 2008, 2009, 2014; Meusburger, P. and Schuch, T. 2010a,b, 2012a,b). Scientific relations can be measured by collaboration in joint research projects (Bukau, B. and Tolle, R. 2012; Raditsch, L. 2012; Seltmann, S. 2012), the distribution of coauthors in joint publications (WeLlnITZ, E.M. 2012), the spatial distribution of former graduates of a professor or faculty (ECKART, W.U. et al. 2012), networks of scholars, the spatial distribution of an author's correspondence (KüHLMANN, W. et al. 2012), and many other indicators.

5 There is a mutual relationship between the reputation of a university and the size and diversity of its recruitment area of professors (MEusburger, P. and Schuch, T. 2010a,b, 2012a,b).

\section{Material and financial resources}

The next important elements of a knowledge environment are its financial resources and the quality of its research infrastructure. Whether outstanding scholars are attracted to a given university often depends on that institution's basic material wherewithal, its financial strength, the quality of its research infrastructure (e.g. physical facilities, libraries, laboratories, and computing centers), and the architecture of a campus. Many new questions can be studied only if the latest research equipment, analytical methods, or archives are on hand. The more expensive such material resources are, the lower the number of universities that are able to acquire them However, philosophers or mathematicians are less place-dependent for their research than experimental physicists, who may find only three locations in Europe where they can conduct their costly experiments.

In order to attract the famous chemist Robert Bunsen (1811-1899) in 1852, the government of the Grand Duchy of Baden funded a stateof-the-art chemistry laboratory building, the most modern in Europe, and probably in the whole world. In the second half of 19th century, the Grand Duchy of Baden spent about 4 percent of its state budget on its two universities and a technical college, and its per capita expenditures on universities exceeded those of any other German state (PfETsCH, F.R. 1974). Robert Bunsen was a prime reason why other exceptional scientists, including Hermann Helmholtz (1821-1894), Robert Kirchhoff (1824-1887) and others joined the staff of Heidelberg University and created a research center of world-wide reputation (for details see ECKART, W.U. et al. 2012; HüBNER, K. 2010; Meusburger, P. 2012a,b).

\section{Immaterial and organisational resources}

Although above-average financial and material endowment is crucial to a university's attractiveness, it by no means guarantees excellent scholarship. Whether an academic 
performs unusually well also depends on a site's various immaterial factors, which constitute the third element of a knowledge environment. Some of them pertain to the institutional regulations, conventions, mutual expectations, and organisational structures under which the scholars try to meet their goals. These factors extend to the questions of how key decisions on structural changes and resource distribution come about within a university. The immaterial factors also include the customary quality standards for research and teaching, the degree of academic freedom, rhetorical strategies of legitimacies (Suddaby, R. and Greenwood, R. 2005), and the issue of whether there is respect for diversity among professional cultures or whether one discipline's rules for evaluating academic performance are imposed on all others. The basic nonmaterial resource of a scientific institution consists largely of the academic reputation ascribed to it.

Institutional theory and research on creativity recognise the constraining effect that institutional norms, conventions, and meaning systems have on the emergence of new theories, new research paradigms, and research methods (Biteктіne, A. and Miller, D. 2015, p. 117). "Actors perceive the meaning of institutions and infuse their actions with meaning based upon these perceptions" (DAcin, M.T. et al. 2002, p. 47). However, members of a university are not passive actors. They are involved in institutional work, and some of them are able to change the rules and meanings of their institution. There is a "dialectical interplay between ... actions (practices and structures), meanings, and actors" (ZILbER, T.B. 2002, p. 235; emphasis in the original; see also DACIN, M.T. et al. 2002, p. 48). Institutional work "describes the practices of individual and collective actors aimed at creating, maintaining, and disrupting institutions" (LAWRENCE, T. et al. 2011, p. 52). Individuals of high social status (high scientific reputation) are better prepared than others to resist and challenge the conforming pressures of institutions (Battilana, J. 2006).

\section{How can a local knowledge environment affect learning and research processes?}

Young scholars and students operate in an environment of "pre-organised knowledge" (KNoblauch, H. 1995, p. 15). Most of them are influenced by what the prominent members of their department or university view to be established knowledge; promising topics, methods, and experiments; and acceptable theories. These up-and-coming academics are inspired or impeded by organisational structures and institutional rules. Their scientific goals and spaces of interaction are influenced by evaluators, role models, critical audiences, institutional regulations, informal expectations of their social environment, and a multitude of other factors. Few students or prospective scientists are able to ignore the expectations and conventions communicated in their social environment.

Institutions, places, locales, and environments are ascribed an indispensable role in the generation of career paths. Just as certain time periods offer different windows of opportunities and risks, certain locales and spatial contexts (Diekmann, A. 2014; Friedrichs, J. and Nonnenmacher, A. 2014) offer different learning opportunities, role models, value systems, challenges, social networks, and opportunities for professional careers. The institutional, cultural, and social context in which a young person studies or in which a young scientist does research and teaches can be elemental in determining the research topics they will find of interest; the methodological skills they will acquire; the scientific networks they are able to join; the kind of critique and support they will encounter; and the interesting, unsolved problems they will notice. Support from key figures in their discipline will affect the initiative, resilience, and subsequent perception that these young academics have of their roles as lecturers and researchers. Daily interaction with positive (or negative) role models and personal relationships has lost none of their significance in the age of the Internet. On the contrary, the overwhelming flood of information has only increased the importance of 
face-to-face contacts with leading thinkers from the relevant disciplines. As a space for experience, perception, or experimentation, the site and surroundings of a university can also give scientific stimulation crucial to research programs, especially in disciplines where field research, spatial data, or expensive experiments are vital.

Knowledge environments can influence the reading or interpretation of scientific knowledge as well. The interpretation and application of new knowledge depend chiefly on the prior knowledge, interests, and prejudices of its potential recipients. A textbook example often cited in Science Studies (Livingstone, D.N. 2003) concerns the reception of Darwin's main work, On the Origin of Species (1859). It was interpreted differently in Russia than in Canada, and differently in Belfast than in Edinburgh. In Charleston it was seen as an argument for racism; in Auckland, as one against it. Immediately after the book was published, the Heidelberg paleontologist Heinrich Georg Bronn (1800-1862), who was also the rector of Heidelberg University at the time, translated it into German, a version that appeared in 1860. Bronn enjoyed a good personal relationship with Darwin. Their bond, though, did not keep Bronn from reading Darwin's work very selectively and incorporating elements of his own perspectives into the translation (Meusburger, P. 2012a, p. 16).

The places where scholars have been academically socialised are very important for their later career. However, scientific careers are not a random sequence of events but rather "contingent series of events" (Welskopp, T. 2002, p. 79) that follow a definite logic and rest on particular mechanisms. In individual cases certain events are therefore linked with each other, and a rationale can be found for the steps in a scholar's career. Prominent scholars indisputably play a major part in shaping the development and careers of talented students. The identity of scholars is defined not only by what they do but also by where they do it. People trust the academic reputation of excellent universities or departments even if unfamiliar with any of the scholars working there. Place names such as Berkeley, Cambridge, or Heidelberg serve as a kind of shorthand for complex circumstances surrounding the practice and standards of science.

What makes a location attractive is its possible or imagined advantages, not the realised ones. Because nobody is able to unravel the complexity of interaction, learning processes, and institutional decision-making, the appraisal of a scientist's potential is closely tied to the places at which that person earned his or her doctorate, did postdoctoral work, or received a professorship. A scholar who was trained at a distinguished research department has credibility from the outset because the scientific reputation of a place or institution is reflected back onto the scholars working there. The history of science is replete with evidence of how a head start translates into a crucial advantage in a scholar's later career and creates important path dependencies.

Each university has its own academic history, body of myths, and major narratives that contribute to a collective identity and reputation. The symbolic meaning, reputation, and attractiveness of a university lie not only in its present merits and achievements but also in those gained previously by scholars no longer belonging to the context. A place is like a screen on which possibilities, expectations, benefits, and hopes are projected. These collective memories and narratives can be reinforced by an iconography of the space and by place-making. Plaques on buildings and memorials constantly remind the informed passer-by of past achievements by famous scientists or of important events in the history of science, imbuing particular places with a symbolic significance as well An awareness of the city's iconography and recurring contact with places important in the history of science can instill in scholars and students an emotional bond and personal identification with their university. It can inspire them with scholarly role models and can create spaces of identity. 


\section{How can the impact of a knowledge environment be measured?}

The study of knowledge environments is a multilevel process at various scales of aggregation, all of which are interconnected. First, the quality of a knowledge environment of academic institutions can be studied for the scientific accomplishments, professional success, or academic reputation attained by their scholars or graduates in a given period. There are numerous questions to pursue in this regard. For instance, what pioneering publications have originated in a particular institute? What new ideas, methods, and theoretical concepts have come from a given institute? How many of an institute's graduates have been appointed to professorships or prominent positions outside academia? How many of a university's scholars have received outstanding scientific awards (e.g., Nobel Prize, Fields Medal, ${ }^{6}$ or honorary doctorates)? How often have its members been engaged as reviewers by international journals and major institutions of research funding or in important evaluation procedures?

This first approach allows inferences about the quality of the knowledge environment without opening the black box of causes and relations and without discussing the personal experiences of the given scholars. This method communicates the external perspective and is useful especially at the highest level of aggregation or with large-scale comparative studies that cannot delve into the biographies of a large number of individual scholars. Figure 1 shows, for example, that former doctoral candidates and assistants of Heidelberg chemist Robert W. Bunsen came to occupy numerous chairs and other prominent positions in the chemistry departments throughout Europe (EсKART, W.U. et al. 2012, p. 98). In addition, a number of prominent U.S. chemists had studied under Bunsen (HonecK, M. and Meusburger, P. 2012).

If so many successful scientists hail from one department, one may legitimately con-

\footnotetext{
${ }^{6}$ International Medal for Outstanding Discoveries in Mathematics.
}

clude that a very stimulating and unusually creative knowledge environment had existed there during a certain period. Such recruitment of scientists to other universities not only promotes knowledge transfer and creates important networks but generally intensifies the sway that the home institutes have over their discipline. Figure 1 also suggests what an international power center Heidelberg must have been in the field of chemistry during the second half of the 19th century. Such internationally important nodes of scientific networks often dominate the review process in recruitment procedures and have a strong impact on scientific journals.

The second approach for studying knowledge environments centers on the social relations, interactions, and networks of the scholars working at a given place and on the processes of appropriation as meant by GRAUMANN and Kruse (Graumann, C.F. 1996, 2002a,b,c; Graumann, C.F. and Kruse, L. 2003). A local cluster of illustrious and globally networked scientists does not automatically equate with knowledge exchange, scientific cooperation, mutual inspiration across disciplines, or a creative environment. Although proximity can facilitate unplanned, spontaneous, face-to-face contact, it does not guarantee interaction. What counts is whether and to what extent the scientists at a university interact and engage in cross-disciplinary discussion (Christmann, G.B. 2013; Keller, R. et al. 2013; KNoblauch, H. 2013; Lepsius, M.R. 2012; Treiber, H. and SAuerland, K. 1995), how they manage their social relations in that environment, and whether the area's creative potential is activated. A knowledge milieu does not emerge until the actors communicate and interact with each other; come to grips with the structural conditions, institutional regulations, and organisational cultures in which they find themselves; and prove themselves willing and able to activate the locally available potential and change organisational structures and conventions. The key words are not cluster or proximity but communicative interaction and ways to transcend the silo mentality. It is the potential to communicate with 


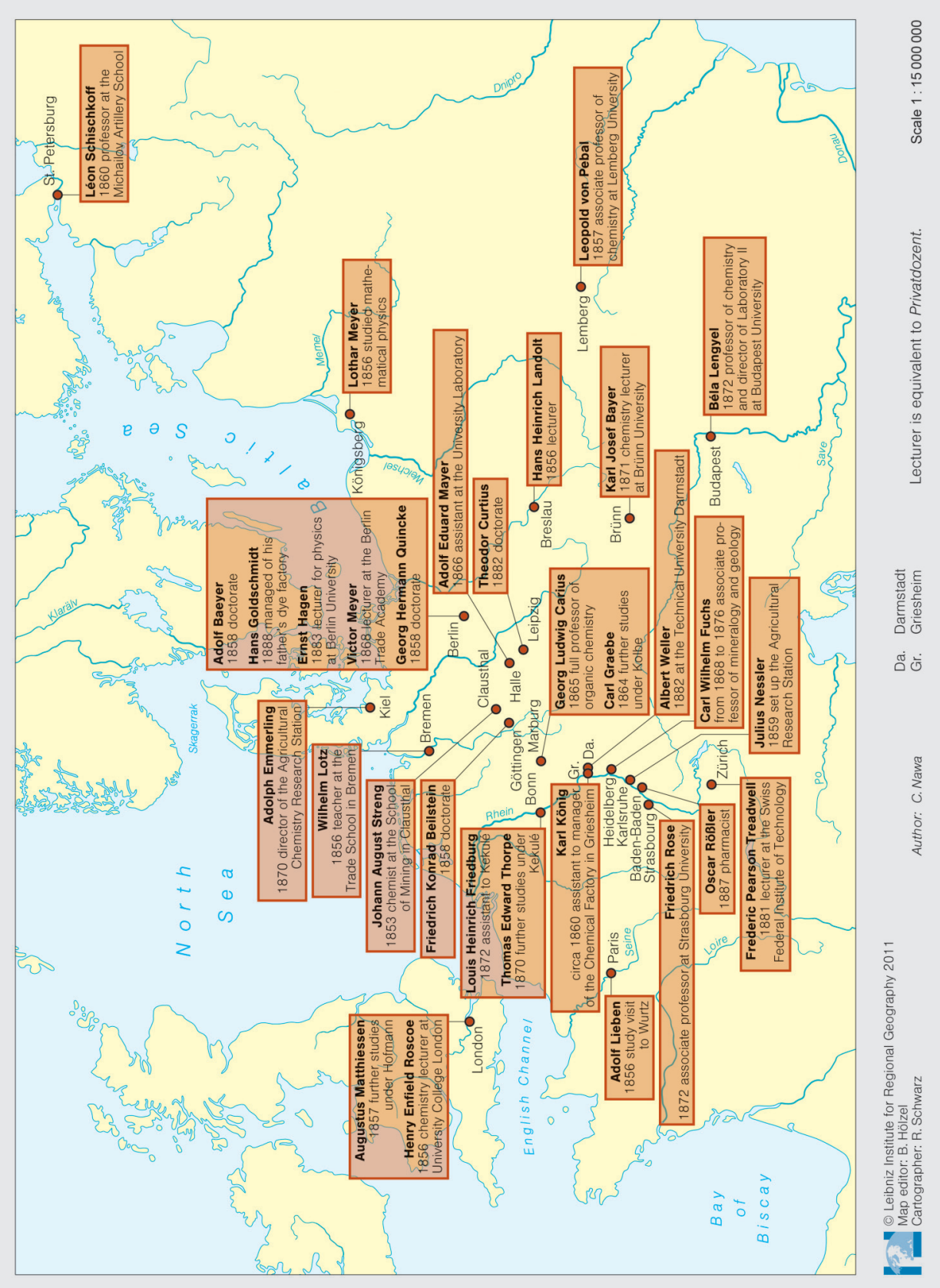

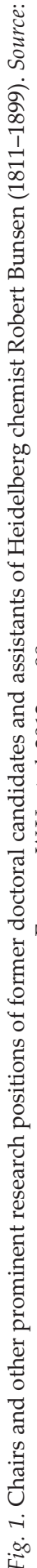


other highly creative persons that attracts artists and scientists from elsewhere.

Processes of appropriation are often taken for granted and underrated, but there are many local opportunities, resources, stimuli, support, services, and challenges that academics may fail to use to their own advantage. Research equipment whose potential is not exploited, books that remain unread, and contacts that are never activated cannot have any effect on learning and research. Without the processes of appropriation, knowledge transfer is impossible in many cases.

The main theories and methodologies of this second approach to the study of knowledge environments are interaction analysis, the microscale of institutional theory ${ }^{7}$ and network analysis. "The dimension of interaction analysis is about clarifying the conditions under which effective problem-solving is achieved or not in the institutionally structured interaction of actors at the meso- and macrolevels" (ScHARpF, F.W. 2002, p. 213). This second approach turns attention to several questions: How do scholars interact with each other? How much are the life worlds of various disciplines at a university or in a knowledge city communicatively interlinked? Which persons or departments are the ones bridging between disciplines or serving as the key nodes in networks? How do people engage with the basic local conditions and power structures under which they try to reach their objectives? How have institutions or individual actors affected these very conditions?

The third way to analyze knowledge environments revolves around the professional career of individual scholars, taking into account what they have subjectively experienced, how they have personally evaluated

\footnotetext{
${ }^{7}$ Issues of power and dominance are widely excluded in the macro-perspectives of institutional theory (see Hudson, B.A. et al. 2015; Willmotr, H. 2015). "In most institutional theory, examination of the relatedness of knowledge and power is deemed to be largely irrelevant; the self-understanding of institutional theory as politically neutral is self-evident; and the silence of institutional theory on contentious issues, such as the institutionalization of domination, oppression, and exploitation in modern work organizations, passes unnoticed" (Willmotт, H. 2015, p. 106).
}

their knowledge environment. According to WeLsкорт "All structural interrelations must . . . be tracked through the consciousness of the participants as it were, although multiple discerning rounds of translation and decoding will be necessary" (WeLsкорт, T. 2002, p. 76).

This approach involves the attempt to reconstruct the influences and watersheds that shaped the academic aspirations, research interests, methodological expertise, and career trajectory in various phases of the particular scholar's career. Most academics are able to recall with relative accuracy who they were decisively influenced and inspired by as students; what personal strengths and weaknesses their professors had; what intellectual standard the doctoral seminars had; the times, places, and people of the critical junctures in their professional success or failure; the time and circumstances relating to their development of a new scientific idea; the way in which their immediate social environment and their academic discipline responded to new ideas; and the reasons that particular research projects could not be pursued. The research taking this approach is based on interviews, memoires, and correspondence; on the scholar's own account of his or her professional career; on biographies and autobiographies; on minutes of meetings; and on reports by persons from the social context. This third approach has a long tradition in the history of science but has been only rarely used to describe knowledge environments.

Most scholars will agree that it is much easier to count organizational structures, financial resources, career steps, networks, scientific awards, scientific accomplishments, patents, impact factors, or the success of a professor's students than it is to measure meaning systems, academic aspirations or the exchange of ideas.

\section{Theoretical concepts contributing to the understanding of knowledge environments}

Anyone interested in the influence of knowledge environments on the learning process- 
es, academic socialization, and the careers of scholars seeks theoretical approaches that can bring out the patterns of interaction and communication between actors, institutions and their environment, and the underlying general mechanisms. These approaches must be able to deal with the tension between a knowledge milieu's conditionality, which is in principle historical and local, and "efforts to formulate generalizing concepts and generic explanations" (Esser, H. 2002, p. 128).

The study of knowledge environments is a multilevel enterprise comprising a broad range of methods and theoretical concepts. It has already been mentioned that creativity research, organization theory, and institutional theory can explain the relations between structure and agency to a certain degree (LAwrence, T. et al. 2011; MintzBerg, H. 1979; Suddaby, R. 2010; Suddaby, R. et al. 2010; ZilbeR, T.B. 2002). Institutional theory provides "new understandings of the manner in which institutions are created, transformed, and extinguished and the way in which institutional processes interact to affect institutional change" (DAcIN, M.T. et al. 2002, p. 45).

"The concept of institutional work insists on the need to consider the permanent recursive and dialectical interaction between agency and institutions. This invites researchers to not only account for the institutional embeddedness of actors but also for their capacity to reflect on this embeddedness, relate to their own self, and develop conscious intentionality. Agency is neither just an effect of the actors' institutional embeddedness nor isolated from this embeddedness. It is an ongoing activity whereby actors reflect on and strategically operate within the institutional context where they are embedded" (LAWrence, T. et al. 2011, p. 55).

In addition to frequently applied concepts focusing on individual actors (e.g., biographical studies), institutions, and organisations, there is a need for concepts focusing on social macrophenomena and holistic explanations (e.g. gestalt psychology, environmental phenomenology). Some scholars hold that one cannot describe place experience, knowledge environments, or life worlds by precisely dis- secting them into constituent parts and then quantitatively "measuring" and modeling the significance of the discrete variables.

Due to the complexity and historicity of the subject, students of knowledge environments are less concerned with the discovery of causalities in the sense of universal laws than with the causal reconstruction of the network of interactions (see MAYNTZ, R. 2002, p. 22). According to MAyntz, what is sought in the empirical analysis of social macrophenomena is "not abstraction and maximal simplification but rather specification and adequate complexity of the explanation" (MaynTz, R. 2002, p. 13). “Causal reconstruction is not about seeking statistical relations between variables but rather about explaining the macro-phenomenon by identifying the processes and interdependencies involved in its having arisen" (MAYnTz, R. 2002. p. 13). Systemic interdependences are about mutual dependence and influence in the relations between different simultaneous processes or between different institutions. The discrete processes or institutions are parametrically linked with each other as it were; that is, they can reciprocally change important basic conditions for each other (Mayntz, R. 2002, p. 33).

In gestalt psychology perception and other mental processes are regarded as holistic rather than atomistic in nature. That is, complex perceptual and cognitive patterns are grasped in their entirety as integral wholes (gestalts), rather than pieced together from simpler sensations or "atoms of experience." A musical melody, for example, is not simply a summation of the individual notes that it contains. The melody is given in experience as a whole, and the character of each individual note is determined by its place within that whole (Schroeder, H.W. 2007, p. 295).

"The starting point for FULLER's phenomenological account of gestalt psychology is the life world of human experience (Fuller, A.R. 1990). "Life world" (Lebenswelt) is a term coined by HusserL to denote the original, meaningful, everyday world in which people actually live. The task of phenomenological description and interpretation is to explicate hidden 
structures of life world meaning that hitherto have been lived only in an implicit, unreflective way" (Schroeder, H.W. 2007, p. 299; see also Husserl, E. 1986).

SEAmon characterises environmental phenomenology as striving for a holistic view of place, in which the various parts of environmental experience are understood as reciprocally related to each other and to the larger geographical whole to which they belong (Seamon, D. 1987). He describes the phenomenological essence of place as "a psycho-social environmental whole larger than the sum of its parts" (p. 20; see also KeEN, E. 1975; McCall, R.J. 1983; Schroeder, H.W. 2007; Seamon, D. 1982).

Communicative constructivism is an approach to explaining how reality (Wirklichkeit) accrues through elaborate processes of transmitting, exchanging, and negotiating thoughts, information, ideas, and messages. Communication is not reduced to language but rather understood as a human practice by which identity, relationship, society, and reality are ascertained, evaluated, and categorized (BERger, P.L. and LuCKMANN, T. 1967; Christmann, G.B. 2013; Keller, R. et al. 2013; Knoblauch, H. 2013).

\section{Conclusion}

Research on knowledge environments will neither replace traditional science studies nor studies about the biographies and careers of individual scholars or studies about academic networks. But studying venues, environments, or social spaces of academic knowledge generation opens up new horizons for explaining interrelations and path dependencies of academic careers and academic achievements.

As with historical theories, knowledge environments can be credited with "a retrospective forecasting ability" (WELSKOPP, T. 2002, p. 83; see also THELEN, K. 2002). In other words, it is possible to formulate a post hoc explanation of how relational networks between human and institutional agents have affected observable scientific practice (see Welskopp, T. 2002, 76-77). The reconstruction and description of knowledge environments after the fact, however, is tied to "epistemological and discursive conditions of the present" (Welskopp, T. 2002, p. 78) and can therefore be revised the moment new information surfaces or scientific standards and criteria of judgment change.

\section{REFERENCES}

Ackers, L. 2005. Moving people and knowledge: Scientific mobility in the European Union. International Migration 43. 99-131.

Aмabile, T.M. 1983a. The social psychology of creativity. New York, Springer, 245 p. DOI: 10.1007/978-14612-5533-8

Amabile, T.M. 1983b. The social psychology of creativity: A componential conceptualisation. Journal of Personality and Social Psychology 45. 357-376.

Amabile, T.M. and Gryskiewicz, N. 1989. The creative environment scales: The work environment inventory. Creative Research Journal 2. 231-254.

Amabile, T.M., Conti, R., Coon, H., Lazenby, J. and Herron, M. 1996. Assessing the work environment for creativity. The Academy of Management Journal 39. 1154-1184.

Amabile, T.M., Goldfarb, P. and Brackfield, S. 1990. Social influences on creativity: Evaluation, co-action, and surveillance. Creativity Research Journal 3. 6-21.

BaAr-Cantoni, R. and Wolgast, E. 2012. Migration of professors between 1550 and 1700. In Wissenschaftsatlas of Heidelberg University. Spatiotemporal relations of academic knowledge production. Eds.: Meusburger, P. and SсHuch, T. Knittlingen, Bibliotheca Palatina, 66-69.

BARKer, R.G. 1968. Ecological psychology. Concepts and methods for studying the environment of human behavior. Stanford, CA, Stanford University Press, 242 p.

Battilana, J. 2006. Agency and institutions: The enabling role of social position. Organization 13. 653-676.

Berger, P.L. and Luckmann, T. 1967. The social construction of reality: a treatise in the sociology of knowledge. New York, Doubleday, 249 p.

Bitektine, A. and Miller, D. 2015. Methods, theories, data, and the social dynamics of organizational research. Journal of Management Inquiry 24. 115-130. DOI: $10.1177 / 1056492614546897$

Boden, M. 1994. What is creativity? In Dimensions of Creativity. Ed.: Boden, M. Cambridge, MA, MIT Press, 75-117.

Boden, M. 2004. In a nutshell. In The Creative Mind. Ed.: Boden, M. London-New York, Routledge, 1-24. 
Bukau, B. and Tolle, R. 2012. The Center for Molecular Biology (ZMBH). In Wissenschaftsatlas of Heidelberg University. Spatio-temporal relations of academic knowledge production. Eds.: Meusburger, P. and $\mathrm{S}_{\mathrm{CHuCH}}, \mathrm{T}$. Knittlingen, Bibliotheca Palatina, 225-227.

Charle, C. 2004. The intellectual networks of two leading universities: Paris and Berlin, 1890-1930. In Transnational intellectual networks. Eds.: CHARLE, C., SChriewer, J. and WAGNER, P. Frankfurt-New York, Campus, 401-450.

Christmann, G.B. 2013. Das theoretische Konzept der kommunikativen Raum(re)konstruktion. Eine Synthese. In Zur kommunikativen Konstruktion von Räumen. Theoretische Konzepte und empirische Analysen. Ed.: Christmann, G.B. Wiesbaden, Springer VS, 89-108.

CLegG, S. 2010. The state, power, and agency: Missing in action in institutional theory? Journal of Management Inquiry 19. 4-13. DOI: 10.1177/1056492609347562

Csikszentminalyi, M. 1988. Society, culture, and person: A systems view of creativity. In The nature of creativity. Ed.: Sternberg, R.J. Cambridge, MA, Cambridge University Press, 325-339.

Csikszentminalyi, M. 1990. The domain of creativity. In Theories of creativity. Eds.: Runco, M.A. and Albert, R.S. Newbury Park, CA, Sage, 190-212.

Csikszentminalyi, M. 1999. Implications of a systems perspective for the study of creativity. In Handbook of creativity. Ed.: Sternberg, R.J. New York, Cambridge University Press, 313-335.

Dacin, M.T., Goodstein, J. and Scott, W.R. 2002. Institutional theory and institutional change: Introduction to the special research forum. Academy of Management Journal 45. 45-57.

Diekmann, A. 2014. Die Anderen als sozialer Kontext. Zur Bedeutung strategischer Interaktion. Kölner Zeitschrift für Soziologie und Sozialpsychologie (Suppl.) 66. 47-66. DOI 10.1007/s11577-014-0258-5

Eckart, W.U., Hübner, K. and Nawa, C. 2012. The rise of the natural sciences - Bunsen, Kirchhoff and Helmholtz. In Wissenschaftsatlas of Heidelberg University. Spatio-temporal relations of academic knowledge production. Eds.: Meusburger, P. and Sснuch, T. Knittlingen, Bibliotheca Palatina, 96-99.

Esser, H. 2002. Was könnte man (heute) unter einer "Theorie mittlerer Reichweite" verstehen? In Akteure - Mechanismen - Modelle. Zur Theoriefähigkeit makrosozialer Analysen. Schriften des Max-Planck-Instituts für Gesellschaftsforschung Köln, Band 42. Ed.: Mayntz, R. Frankfurt-New York, Campus, 128-150.

Friedrichs, J. and-Nonnenmacher, A. 2014. Die Analyse sozialer Kontexte. Kölner Zeitschrift für Soziologie und Sozialpsychologie (Suppl.) 66. 1-16. DOI: 10.1007/ s11577-014-0260-y

FulLer, A.R. 1990. Insight into value: An exploration of the premises of a phenomenological psychology. Albany, NY. State University of New York Press, 236 p.
Gieryn, T.F. 2001. Sociology of science. In International Encyclopedia of the Social \& Behavioral Sciences. Vol. 20. Eds.: SMELSER, N.J. and BALtes, P.B. Amsterdam, Elsevier, 13692-13698.

Gieryn, T.F. 2002. Three truth-spots. Journal of the History of Behavioral Sciences 38. 113-132. DOI: 10.1002/jhbs.10036

GLÜCKLER, J. 2013. Knowledge, networks and space: Connectivity and the problem of non-interactive learning. Regional Studies 47. 880-894.

Graumann, C.F. 1996. Aneignung. In Ökologische Psychologie. Ein Handbuch in Schlüsselbegriffen. Eds.: Kruse, L., Graumann, C.F. and Lantermann, E. Weinheim, Psychologie Verlags Union, 124-130.

Graumann, C.F. 2002a. Zwischen den Disziplinen. Dilemma und Chancen der Umweltpsychologie. Umweltpsychologie 6. 154-161.

Graumann, C.F. 2002b. The phenomenological approach to people-environment studies. In Handbook of Environmental Psychology. Eds.: Bechtel, R.B. and Churchman, A. New York, Wiley, 95-113.

GraumanN, C.F. 2002c. Auf dem Wege zu einer humanökologischen Psychologie. Zu Florian Kaisers Replik. Umweltpsychologie 6. (2): 82-83.

Graumann, C.F. and Kruse, L. 2003. Räumliche Umwelt. Die Perspektive der humanökologisch orientierten Umweltpsychologie. In Humanökologie: Ansätze zur Überwindung der Natur-KulturDichotomie. Erdkundliches Wissen, Vol. 135. Eds.: Meusburger, P. and Schwan, T. Stuttgart, Steiner, 239-256.

Harvey, D. 2005. Space as a key word. Hettner Lectures 8. Stuttgart, Steiner, 93-115.

Harvey, W. 2010. British and Indian scientists moving to the United States. Work and Occupations 38. 68-100.

Heffernan, M. and Jöns, H. 2013. Research travel and disciplinary identities in the University of Cambridge, 1885-1955. The British Journal for the History of Science 46. 255-286.

Hennessey, B.A. and Amabile, T.M. 1988. The conditions of creativity. In The nature of creativity. Ed.: Sternberg, R.J. Cambridge, England, Cambridge University Press, 11-38.

Honeck, M. and Meusburger, P. 2012. American Students up to 1914. In Wissenschaftsatlas of Heidelberg University. Spatio-temporal relations of academic knowledge production. Eds.: Meusburger, P. and SсHUCH, T. Knittlingen, Bibliotheca Palatina, 296-299.

Hübner, K. 2010. Gustav Robert Kirchhoff. Das gewöhnliche Leben eines außergewöhnlichen Mannes. Schriften, Archiv und Museum der Universität Heidelberg 16. Heidelberg, Verlag Regionalkultur, UbstadtWeiher, $311 \mathrm{p}$.

Hudson, B.A., Okhursen, G.A. and Creed, W.E.D. 2015. Power and institutions: Stones in the road and some yellow bricks. Journal of Management Inquiry 24. 233-238. DOI: 10.1177/1056492614565240 
Husserl, E. 1986. Phänomenologie der Lebenswelt. Stuttgart, Reclam, 303 p.

Jöns, H. 2007. Transnational mobility and the spaces of knowledge production: A comparison of global patterns, motivations and collaborations in different academic fields. Social Geography 2. 97-114.

Jöns, H. 2008. Academic travel from Cambridge University and the formation of centres of knowledge, 1885-1954. Journal of Historical Geography 34. 338-362.

JöNs, H. 2009. Brain circulation' and transnational knowledge networks: Studying long-term effects of academic mobility to Germany, 1954-2000. Global Networks 9. 315-338.

Jöns, H. 2014. Talent mobility and the shifting geographies of Latourian knowledge hubs. Population, Space and Place. Published online in Wiley Online Library (wileyonlinelibrary.com) DOI: 10.1002/ psp. 1878

KeEN, E. 1975. A primer in phenomenological psychology. New York, Holt, Rinehart and Winston, 184 p.

Keller, R., Knoblauch, H. and Reichertz, J. 2013. Der Kommunikative Konstruktivismus als Weiterführung des Sozialkonstruktivismus - eine Einführung. In Kommunikativer Konstruktivismus. Theoretische und empirische Arbeiten zu einem neuen wissenssoziologischen Ansatz. Eds.: Keller, R., Knoblauch, H. and Reichertz, J. Wiesbaden, Springer VS, 9-21.

Knoblauch, H. 1995. Kommunikationskultur. Die kommunikative Konstruktion kultureller Kontexte. Berlin, de Gruyter, 338 p..

Knoblauch, H. 2013. Über die kommunikative Konstruktion der Wirklichkeit. In Zur kommunikativen Konstruktion von Räumen. Theoretische Konzepte und empirische Analysen. Ed.: Christmann, G.B. Wiesbaden, Springer VS, 29-53.

Kühlmann, W., Hartmann, V. and El Kholi, S. 2012. The golden age of late Humanism (ca. 1560 to 1622). In Wissenschaftsatlas of Heidelberg University. Spatiotemporal relations of academic knowledge production. Eds.: Meusburger, P. and Schuch, T. Knittlingen, Bibliotheca Palatina, 60-61.

Lawrence, T., Suddaby, R., and Leca, B. 2011. Institutional work: Refocusing institutional studies of organization. Journal of Management Inquiry 20. 52-58. DOI: $10.1177 / 1056492610387222$

LePsius, M.R. 2012. Intellectual circles at the beginning of the $20^{\text {th }}$ century. In Wissenschaftsatlas of Heidelberg University. Spatio-temporal relations of academic knowledge production. Eds.: Meusburger, P. and SCHuCh, T. Knittlingen, Bibliotheca Palatina, 112-113.

Livingstone, D.N. 1995. The spaces of knowledge: Contributions towards a historical geography of science. Environment and Planning D: Society and Space 13. 5-34.

Livingstone, D.N. 2000. Making space for science. Erdkunde 54. 285-296.
Livingstone, D.N. 2002. Knowledge, space and the geographies of science. Hettner Lectures 5. Heidelberg, Department of Geography, Heidelberg University, $7-40$.

Livingstone, D.N. 2003. Putting science in its place. geographies of scientific knowledge. Chicago, University of Chicago Press, 234 p.

Mager, C. 2012. Heidelberg Nobel Prize winners. In Wissenschaftsatlas of Heidelberg University. Spatiotemporal relations of academic knowledge production. Eds.: Meusburger, P. and Schuch, T. Knittlingen, Bibliotheca Palatina, 250-253.

Malecki, E.J. 2013. Creativity: who, how, where? In Knowledge and the economy. Knowledge and Space, Vol. 5. Eds.: Meusburger, P., Glǘckler, J. and El Meskioui, M. Dordrecht, Springer, 79-93.

Massey, D. 1999. Philosophy and politics of spatiality: Some considerations. Hettner Lectures 2. Heidelberg, Heidelberg University, Department of Geography, 27-42.

Massey, D. 2005. For space. London, Sage, 222 p..

Matthiesen, U. 2009. Knowledge Scapes: A new conceptual approach and selected empirical findings from recent research on knowledge milieus and knowledge networks. disP-The Planning Review 177. (2): 10-28.

Mayntz, R. 2002. Zur Theoriefähigkeit makro-sozialer Analysen. In Akteure-Mechanismen-Modelle. Zur Theoriefähigkeit makro-sozialer Analysen. Schriften des Max-Planck-Instituts für Gesellschaftsforschung Köln, Band 42. Ed.: Mayntz, R. Frankfurt-New York, Campus, 7-43.

McCall, R.J. 1983. Phenomenological psychology: An introduction. Madison, WI, The University of Wisconsin Press, 140 p.

Meusburger, P. 2008. The nexus between knowledge and space. In Clashes of knowledge. Orthodoxies and heterodoxies in science and religion. Knowledge and Space, Vol. 1. Eds.: Meusburger, P., Welker, M. and Wunder, E. Dordrecht, Springer, 35-90.

Meusburger, P. 2009a. Milieus of creativity. The role of places, environments, and spatial contexts. In Milieus of Creativity. An Interdisciplinary Approach to Spatiality of Creativity. Knowledge and Space, Vol. 2. Eds.: Meusburger, P., Funke, J. and Wunder, E. Dordrecht, Springer, 97-153.

Meusburger, P. 2009b. Spatial mobility of knowledge: A proposal for a more realistic communication model. disP - The Planning Review 177. (2): 29-39.

Meusburger, P. 2012a. Wissenschaftsatlas of Heidelberg University - An Introduction. In Wissenschaftsatlas of Heidelberg University. Spatiotemporal relations of academic knowledge production. Eds.: Meusburger, P. and Schuch, T. Knittlingen, Bibliotheca Palatina, 12-17.

Meusburger, P. 2012b. Heidelberg: Relations between a town and its university. In Wissenschaftsatlas of Heidelberg University. Spatio-temporal relations of aca- 
demic knowledge production. Eds.: Meusburger, P. and Schuch, T. Knittlingen, Bibliotheca Palatina, 18-35.

Meusburger, P. and Schuch, T. 2010a. Karrieren, soziale Herkunft und räumliche Mobilität der Heidelberger Professoren 1803-1932. In Akademische Lebenswelten. Habitus und Sozialprofil von Gelehrten im 19. und 20. Jahrhundert. Eds.: Dемм, E. and Suchoples, J. Frankfurt am Main, Peter Lang Verlag, 217-249.

Meusburger, P. and Schuch, T. 2010b. From mediocrity and existential crisis to scientific excellence: Heidelberg University between 1803 and 1932. In Geographies of science. Knowledge and Space 3. Eds.: Meusburger, P., Livingstone, D.N. and Jöns, H. Dordrecht, Springer, 57-93.

Meusburger, P. and Schuch, T. 2012a. Regional provenance and social background of professors 1803 to 1932. In Wissenschaftsatlas of Heidelberg University. Spatio-temporal relations of academic knowledge production. Eds.: Meusburger, P. and $\mathrm{S}_{\mathrm{CHuch}}$, T. Knittlingen, Bibliotheca Palatina, 78-81.

Meusburger, P. and Schuch, T. 2012b. Whence they came: Heidelberg University's professors 1945 to 2010. In Wissenschaftsatlas of Heidelberg University. Spatio-temporal relations of academic knowledge production. Eds.: Meusburger, P. and Schuch, T. Knittlingen, Bibliotheca Palatina, 262-265.

Meusburger, P., Funke, J. and Wunder, E. 2009. Introduction: The spatiality of creativity. In: Milieus of Creativity. An Interdisciplinary Approach to Spatiality of Creativity. Knowledge and Space, Vol. 2. Eds.: Meusburger, P., Funke, J. and Wunder, E. Dordrecht, Springer, 1-10.

Mintzberg, H. 1979. The structuring of organizations: A synthesis of the research. Englewood Cliffs, NJ, Prentice Hall, 512 p.

Mumford, M.D. 1995. Situational influences on creative achievement: Attributions or interactions? Creativity Research Journal 8. 405-412.

Ophir, A. and Shapin, S. 1991. The place of knowledge: The spatial setting and its relations to the production of knowledge (Special issue). Science in Context 4. 3-21.

Pfetsch, F.R. 1974. Zur Entwicklung der Wissenschaftspolitik in Deutschland, 1750-1914. Berlin, Duncker and Humblot, 359 p.

Raditsch, L. 2012. European Molecular Biology Laboratory (EMBL). In Wissenschaftsatlas of Heidelberg University. Spatio-temporal relations of academic knowledge production. Eds.: Meusburger, P. and SсHuch, T. Knittlingen, Bibliotheca Palatina, 288-289.

RAudSEPP, E. 1958. The industrial climate for creativity: An opinion study of 105 experts. Management Review 47. 4-8, 70-75.

Rowles, G.D. 2008. Place in occupational science: A life course perspective on the role of environmental context in the quest for meaning. Journal of Occupational Science 15. 127-135.
Runco, M.A. 1988. Creativity research: Originality, utility, and integration. Creativity Research Journal 1. 1-7.

Runco, M.A. and Окuda, S.M. 1988. Problem discovery, divergent thinking, and the creative process. Journal of Youth and Adolescence 17. 213-222.

Scharpf, F.W. 2002. Kontingente Generalisierung in der Politikforschung. In Akteure-Mechanismen-Modelle. Zur Theoriefähigkeit makro-sozialer Analysen. Schriften des Max-Planck-Instituts für Gesellschaftsforschung Köln, Band 42. Ed.: Mayntz, R. Frankfurt-New York, Campus, 213-235.

Schroeder, H.W. 2007. Place experience, gestalt, and the human-nature relationship. Journal of Environmental Psychology 27. 293-309.

SEAmon, D. 1982. The phenomenological contribution to environmental psychology. Journal of Environmental Psychology 2. 119-140.

SEAmON, D. 1987. Phenomenology and environment-behavior research. In Advances in environment, and behavior design, Vol. 1. Eds.: ZubE, E.H. and Moore, G.T. New York, Plenum Press, 3-27.

Seltmann, S. 2012. The German Cancer Research Center (DKFZ). In Wissenschaftsatlas of Heidelberg University. Spatio-temporal relations of academic knowledge production. Eds.: Meusburger, P. and Schuch, T. Knittlingen, Bibliotheca Palatina, 284-285.

Shapin, S. 1998. Placing the view from nowhere: Historical and sociological problems in the location of science. Transactions of the Institute of British Geographers 23. 5-12.

SHapIN, S. 2001. Truth and credibility: Science and the social study of science. In International encyclopedia of the social and behavioral sciences. Vol. 23. Eds.: SMELSER, N.J. and BALtes, P.B. Amsterdam, Elsevier, 15926-15932.

SimonTon, D.K. 1975. Sociocultural context of individual creativity: A transhistorical time-series analysis. Journal of Personality and Social Psychology 32. 1119-1133.

Sternberg, R.E. and Lubart, T.I. 1991. An investment theory of creativity and its development. Human Development 34. 1-32.

Sternberg, R.E. and Lubart, T.I. 1999. The concept of creativity: Prospects and paradigms. In Handbook of creativity. Ed.: Sternberg, R.J. New York, Cambridge University Press, 3-15.

Suddaby, R. 2010. Challenges for institutional theory. Journal of Management Inquiry 19. 14-20. DOI: $10.1177 / 1056492609347564$

Suddaby, R. and GreEnwood, R. 2005. Rhetorical strategies of legitimacies. Administrative Science Quarterly 50. 35-67.

Suddaby, R., Elsbach, K.D., Greenwood, R., Meyer, J.W. and Zilber, T.B. 2010. Organizations and their institutional environments. Bringing meaning, values, and culture back in: Introduction to the special research forum. Academy of Management Journal 53. 1234-1240.

Thelen, K. 2002. The explanatory power of historical institutionalism. In Akteure - Mechanismen 
- Modelle. Zur Theoriefähigkeit makro-sozialer Analysen. Schriften des Max-Planck-Instituts für Gesellschaftsforschung Köln, Band 42. Ed.: Mayntz, R. Frankfurt-New York, Campus, 92-107.

Treiber, H. and Sauerland, K. 1995. Heidelberg im Schnittpunkt intellektueller Kreise. Zur Topographie der "geistigen Geselligkeit" eines Weltdorfes. Opladen, Westdeutscher Verlag, 563 p..

Wellnitz, E.M. 2012. Medical faculty Mannheim. In Wissenschaftsatlas of Heidelberg University. Spatiotemporal relations of academic knowledge production. Eds.: Meusburger, P. and Schuch, T. Knittlingen, Bibliotheca Palatina, 166-169.

Welsкорт, T. 2002. Die Theoriefähigkeit der Geschichtswissenschaft. In Akteure-Mechanismen
- Modelle. Zur Theoriefähigkeit makro-sozialer Analysen. Schriften des Max-Planck-Instituts für Gesellschaftsforschung Köln, Band 42. Ed.: MAYnTZ, R. Frankfurt-New York, Campus, 61-90.

Willmotт, H. 2015. Why institutional theory cannot be critical. Journal of Management Inquiry 24. 105-111. DOI: 10.1177/1056492614545306

Withers, C.W.J. 2002. The geography of scientific knowledge. In Göttingen and the Development of the Natural Sciences. Ed.: RupKe, N.A. Göttingen, Wallstein Verlag, 9-18.

ZILBER, T.B. 2002. Institutionalization as an interplay between actions, meanings, and actors: The case of a rape crisis center in Israel. Academy of Management Journal 45. 234-254. 


\title{
AQUINCUM Ancient landscape - Ancient town
}

\author{
Edited by \\ Katalin H. Kérdô and Ferenc Schweitzer \\ Geographical Institute Research Centre for Astronomy and Earth Sciences HAS
}

Budapest, 2014. 188 p.

Geomorphological-paleoenvironmental studies supporting archeological excavations and investigations are to be considered a new trend within the broader sphere of studies on environment and geomorphology. By publishing the latest achievements of researches of this kind carried out on the territory of Aquincum and in its wider surroundings this book may equally reckon on the interest of professional circles and inquiring audience.

Therefore the publication of such a volume of somewhat unusual character is welcome. The project could be completed as a result of the close cooperation of two important branches of studies, notably geography and archeology. They both have long lasting traditions in our country and on this occasion were represented by two prominent institutions, the Geographical Institute of the Hungarian Academy of Sciences, and the Aquincum Museum of the Budapest History Museum. Their contribution has made possible the publication of this book.

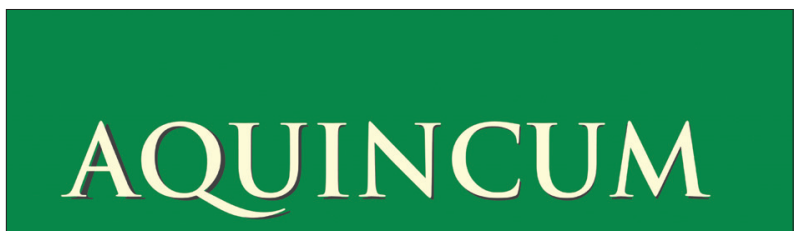

Ancient landscape - ancient town

Edited by:

Katalin H. Kérdő - Ferenc Schweitzer

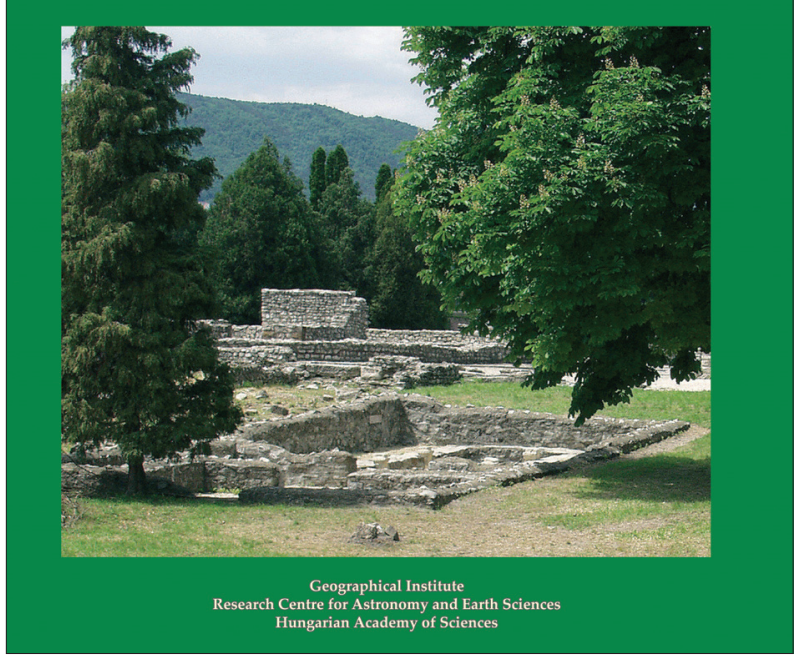

The studies were aimed to clear up the role of those natural factors which exerted a profound influence on the development of the settlement structure during the Roman Period. Romans had a special ability to realize advantages provided by geomorphological characteristics and they had made a good use of natural waters, flood-plain surface features and parent rocks for their creativity.

The volume is also deemed as a pioneering work with regard to the richly illustrated presentation of geological, geographical and other natural features exposed in several places in the course of archeological excavations. A short summary shows the most important objects of the Roman Period related to natural endowments and traces of activities of the time leading to environmental transformation.

Based on geomorphological evidence a new answer is proposed to a previously raised problem whether the Hajógyári Island existed as an islet already in the time of the Romans. Another intriguing issue tackled is the purpose of the system of trenches found in several places along the Danube River.

Price: EUR 20.00

Order: Geographical Institute of RCAES HAS.H-1112 Budapest, Budaörsi u. 44. E-mail: magyar.arpad@csfk.mta.hu 